International Journal of Social Sciences and Humanities
Available online at http://sciencescholar.us/journal/index.php/ijssh
Vol. 2 No. 2, August 2018, pages: 175 186
e-ISSN: 2550-7001, p-ISSN: 2550-701X
https://doi.org/10.29332/ijssh.v2n2.162

\title{
Pronouns Traces of Grammar Transformation Version of Government and Binding
}




Conflict of interest statement and funding sources......................................................................................... 184

Statement of authorship ....................................................................................................................................... 184

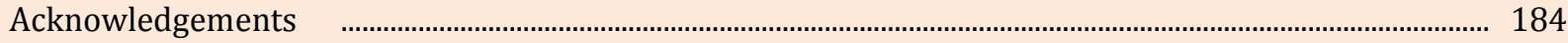

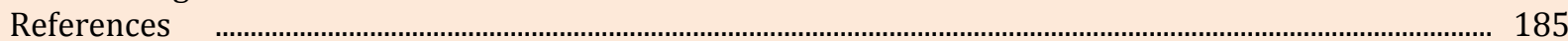

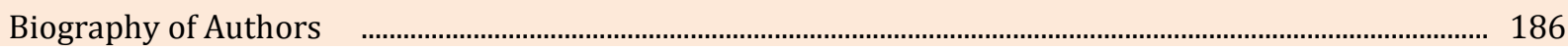

\section{Introduction}

The study of Nusantara languages using structural theory has been widely applied but it can be stated that study using the framework of Government and Binding theory (GB) is rarely found. Some studies on the Indonesian language have been done such as: "Strukur Frase Bahasa Indonesia: Sebuah Kajian Berdasarkan Teori X-bar"; (2) "Strukur Frase: Kajian Berdasarkan Teori X-bar" (Paridi, 1997); (3) Government and Case (Paridi, 2001). Based on the results of these studies, there is no specific study of pronominal viewed from transformation theory. Thus, the study of Nusantara languages (BS) can be continued as a testing ground to test the universality of the claims of the theory.

The problems focused to be examined in this study are how the description of the personal pronoun is contained in a single sentence in BS?; how the semantic role of personal pronouns in a single sentence in BS is? from which the semantic role is found in the personal pronouns contained in a sentence in BS? what is the trace of personal pronouns when experiencing the transfer in BS?

\section{Research Method}

To gather sufficient data, this study uses two data collection methods namely (a) linguistic field method and (b) literature research method. The data gathered were then analyzed by using the distributional method. This method is done by connecting or integrating phenomena in a language without integrating it with the non-linguistic elements (Sudaryanto, 1986:4). Some techniques can be applied such as deletion, substitution, insertion, and permutation/transfer to ease the analysis method, To present the data analyzed, two techniques were then employed including formal and informal techniques (Iriani: 2018, Ruan: 2018, Anita: 2018).

\section{Theory}

The theoretical approach used to analyze the phenomenon of the personal pronoun in BS in this study is the theory of Government and Binding (Chomsky, 1981). This theory claims that all languages in the world have a universal nature (Universal Grammar) that is modular.

Through the modular theory, it is predicted that syntactic complexity can be expressed. Therefore, GB theory has several subsystems namely X-bar theory, Case theory, Bounding theory, Binding theory, Government theory, Control theory, and Theta theory. Thus, each language is expected to follow the general principle claimed by the theory.

To examine the phenomenon of personal pronouns in BS, this study uses Trace theory. Chomsky (1986) suggests that Trace Theory can be explained by case theory (Case Theory). This theory explains that: 1) $N P$ (case filter: each $N P$ should accept the case, 2) to accept case $N P$ must be governed and must be C-commanded by element giving case; 2) nominative cases will be provided by AGR co-indent; and by the head verbs.

Based on the aforementioned explanation, the noun phrase, the personal pronoun must accept the case. And, this pronominal may experience displacement according to the direction of the case causing the displacement. In this case, the base position will be empty after moving to another position. This event will leave a trace in the position it left behind. Elements that have been moved are called antecedent. These reasons underlie Trace's theory.

The background that bases this trace is generally on the principle of projection; besides, it is also based on the theta role on any nouns present. The grammatical component in GB theory discussing the theta role is called the theta theory. (Chomsky 1981, 1986) explains that every theta role must have an argument and every argument must get a theta role. and the case (Case). Therefore, case filters are not independent 
grammatical principles, but they arise because of the appearance of functions and the position of noun phrases.

There are two pronominal types: first, pronominal in the form of lexeme (unbound). This first type of pronominal consists of elements: aku 'saya' 'I/Me', ie 'dia' (he/she/her/him), ite 'kita' (we/us), kemi 'kami' (we/us), and side 'anda' (you); the second is a pronominal form similar to that of clitic. The existence of this pronominal type is always mutually excluded with the form of clitic. This form can Semantically stand alone and can replace the position of the subject NP, while the form clitic cannot stand alone and cannot replace the position of the subject NP in the sentence (Paridi, 1997: 67); (Setiawan, 2016).

Furthermore, it is argued in the example that pronominal categories such as' $-k u$ /' I/ me ', -ne' he/she/him/her ', /'them' (both male and female), -te 'us' (male, female), -me? 'You' (male), -bi 'you' (female); different from my - $k u$ 'I' markers, -ne 'he/she', / them '(male, female), -te' us' (male, female), -me? 'You' (male), - $b i$ 'you' (female) who serves as clitic. Furthermore, the marker is predicted as an AGR marker in the finite clause (Paridi, 1997: 68).

This bound pronominal element can follow the subject's NP, and its form must agree with the NP that it attaches. This pronominal existence is almost similar with the Indonesian clitic form and the agreement marker in English which has a genetical case. To distinguish whether the above forms function as pronominal, or as a clause, its existence can be identified from the semantic elements of the subject NP that it follows. If the NP is followed by the NP expressing the meaning of ownership, the form including its climatic form and its existence cannot replace the subject's NP position. In contrast to the second type of pronominal which can replace the subject's NP position and semantically does not state the meaning of ownership. The existence of this form in terms of grammatical relations can stand alone in the sentence. Look at the bounded form in the NP below that state the meaning of possession: bangket-ne 'his or her rice field', bangket-ku 'my rice field', bangket-me?' your rice field' male), bangket-bi 'your rice field (female), bangket-te 'our rice field'

\section{Results and Analysis}

\section{Discussion}

There are two lexical markers used to mark the difference of events or circumstances: first, an aspect of the word gen 'will' used o mark events or circumstances that will occur, oah 'already' used to mark events or circumstances that have occurred, and kenyengke ' is/am/are/doing' used to mark events or circumstances that are happening; second, the element of modalities consisting of the word kanggo 'may',might', harus 'must', bau 'can / could, mele 'want'. The two elements mentioned in this paper are referred to as the Verbs of Work (KKB). In the representation of the tree diagram, the element is dominated under the node (node) of Modal (M).

\subsection{Main Sentence}

The main sentence in the BS can be formed by $N P$ that serves as a subject and $N P$ that serves as a predicate. It needs to keep in mind that in such sentences the subject $N P$ and the free pronominal function as the subject and cannot be replaced by the non-free pronominal that can play as the subject. Similarly, it is also the same as if the predicate belongs to PP subject of the sentence, it cannot be filled by the pronominal that is not free. If the subject's NP is filled with a non-free pronominal, the sentence will be unacceptable in the BS. See the sentences below.

$$
\begin{aligned}
& \text { a. Ie (he or she) guru (teacher) } \\
& \text { NP subject NP predicate } \\
& \text { Pron.diaguru (he or she is a teacher) } \\
& \text { b. Adi? (Brother/sister) pegawe (worker) } \\
& \text { NP subject NP predicate } \\
& \text { Adik pegawai (Brother or sister is a worker) } \\
& \text { c. } \quad \text { Ne(he or she) guru(teacher) }
\end{aligned}
$$

Paridi, K., \& Sudika, I. N. (2018). Pronouns traces of grammar transformation version of government and binding. International Journal of Social Sciences and Humanities, 2(2), 175-186. https://doi.org/10.29332/ijssh.v2n2.162 


\section{pron.diaguru \\ Dia seorang guru (he or she is a teacher) \\ d.* Ne (he or she) le? (in) bangket (the rice field) \\ pron.Subject FP pred. sawah \\ Dia di sawah (he or she is in the rice field)}

It is different if the main sentence is constructed from the subject of a sentence categorized as NP and predicated on the category of VP or AP, all types of categories are subject NP, ordinary pronominal and pronominal of the second type can fill the position of sentence subject. We can see the sentences below.
a. Ine? (mother) lalo. (go)
$\mathrm{N}$-subject V-predicate
Ibu pergi. (mother is going)
b. Ne (he or she) lelah (tired)
pron.Subject Ajek.lelah
Dia lelah (he or she is tired)
c. Ie (he or she) sakit (sick)
Pron. Subject Ajek.predicate
Dia sakit (she is sick)
Pron.Subject FP disawah
Dia di sawah (he or she is in the ricefield)
d. Ie (he or she) le? (in) bangket (rice field)

The main sentences (2a) and (2b) can also be extended by using other elements. We can see from how a nonfree pronominal can follow a regular NP as if it plays like a general clause (2c). However, essentially, the element is pronominal because its existence in the sentence can replace an ordinary NP that can stand alone as a subject, as shown in a sentence (3b). In contrast to example (3c) which is a clitic example which expresses the meaning of possession. See the examples below:
a. Ine? (mother) -ne lalo. (go_
Ibu pron pergi
Ibu pergi (mother is going)
b. $\quad$ Ne (he or she) lalo (go)
pron pergi
Dia pergi (she or he is going)
$\begin{array}{lll}\text { c. } & \text { Ine (mother) ne (his or her) lalo. (go) } \\ \text { ibu Cl. } & \text { pergi }\end{array}$
Ibunya pergi (his or her mother is going)

From the sentence (3) above, the pronominal presence which is not free in the BS is almost similar to the English genitive case, but its presence in the NP cannot be said to have a genitive case and cannot be called as clitic for the form can stand alone in the sentence. To be able to see the differences between the three types of forms, we can see the examples of the main sentence that are expanded with the following other elements.
(4) a.Gen (will)
-ne (he or she) lalo (go)
Asp. pron pergi 
Dia akan pergi (he or she will go)

b.Ine?(mother) gen (will) -ne (his or her) njual (sell) bangket-ne (his or her rice field)

Ibu Asp pron menjual sawah Cl.nya

Ibu akan menjual sawahnya (mother will sell her rice field)

$\begin{array}{lllll}\text { c. } A k u(I) & \text { gen (will) } & -k u(I) \text { njual (sell) } & \text { bangket (rice field) } & -k u(m y) \\ \text { Pron Asp pron menjual sawah pron. } & \end{array}$

Saya akan menjual sawah saya (I will sell my rice field)

d.Ame (father) -ne (his or her) gen(will) -ne (his or her) njual (sell) bangket -ne (his or her rice field)

Ayah pron.nya akan pron menjual sawah pron.

Ayahnya akan menjual sawahnya (his or her father will sell his rice field)

\subsection{The element of aspect as auxiliary verb}

In the BS, the auxiliary Verb (KKB) can consist of the word aspect and Modality, yet the focus of this study is on aspect example. It is because the element is in the same position that is under the vertex $M$ in the representation of the tree diagram. For being deeply understanding, the definition and example of the word aspect are represented. The word aspect is a closed class of lexical. The element of this aspect consists of lexical such as oah 'already', kenyengke 'is/am/are doing' and gen 'will'. The element of this aspect can be presented in various constructions, except in Imperative construction. To prove the existence of these aspects, let see the distribution of the use of aspects in the sentences below.



b. Indah (Indah) gen (will) sekolah (school) Indah Asp.akan sekolah Indah akan sekolah (Indah will go to school)

c. Indah (Indah) gen (will) -ne (he or she) sekolah (school). Indah Asp.akan pron.diasekolah Indah akan sekolah. (Indah will go to school)

d.* Indah (Indah) -ne (he or she) gen (will) sekolah (shcool) Indah pron. Asp.akan sekolah Indah akan sekolah (Indah will go to school)

e.* Indah (Indah) -ne (he or she) sekolah sekolah (shcool) gen (will) Indah pron sekolah Asp.akan

Indah akan sekolah (Indah will go to school)

$\begin{array}{lll}\text { f. } & \text { Gen (will) } & \text {-ne (he or she) lalo (go) } \\ \text { Asp.akan pron pergi } & \end{array}$

Dia akan pergi (he or she will go)

g. Ne sekolah. (he or she) (school)

pron. sekolah

Dia sekolah (he or she goes to school

Paridi, K., \& Sudika, I. N. (2018). Pronouns traces of grammar transformation version of government and binding. International Journal of Social Sciences and Humanities, 2(2), 175-186. https://doi.org/10.29332/ijssh.v2n2.162 
Concerning on description of the presence of the aspect in the above example, it can be identified that the element of aspect can almost appear in various constructions, except in imperative construction. From the above sentence (5), it shows that the element of aspect may be in a position before the verb. If pronominal is present, the aspect may be in the pronominal position since the pronominal is inflected in the aspect. If its position is changed to the post pronominal position, the sentence becomes grammatical as seen in example (5d). The position of the aspect also cannot be placed after the verb; otherwise, the sentence becomes grammatical, as in example (5e). The element of aspect may also fill the starting position of the sentence if the subject NP does not exist as in example (5f). Let see the Wh-question construction that presents the aspects below.



In the Wh-question, the position of the aspect can fill the position after Aux si (that is) and before the verb. If the position is changed to the position before Aux si and after the verb, the sentence becomes ungrammatical as the example (6b) (6c). Likewise, if the Pron. Element exists in the sentence, it becomes grammatical as it does in construction (6d). see the construction of the negation below.

a. Ndara? (nothing) adi?(younger brother or sister) oah (already) sekolah (school)

Neg. adik. Asp.sudah sekolah

Tidak ada adik pernah sekolah. (no younger sister or brother already went to school) b.* Ndara? (nothing) oah (already) adik(younger brother or sister) sekolah (school)
Neg. Asp.sudah adik sekolah

Tidak ada adik sudah sekolah (no younger sister or brother already went to school)

c.* Ndara? (nothing) adi? (younger brother or sister) oah (already) -ne (he or she) sekolah(school)

Neg. adik Asp. pron sekolah

Tidak ada adik pernah sekolah (no younger sister or brother already went to school)

d. Adi?(younger brother or sister) ndara?(nothing) oah (already) sekolah (school) Adik Neg. Asp.sudah sekolah

Adik tidak pernah sekolah (younger brother os sister never goes to school)

In the negation construction in Example 7 it shows that the position of the element of aspect is after the subject NP as Example 7a and if it is a negation element exists, the position of the aspect is in position after the negation and before the verb. If the position is changed for example to the position before the negation element, the sentence becomes ungrammatical as in example (7b), and if the pronominal element exists, the sentence constructed will not be grammatical (7c). we can see the constructions of the imperative sentence below. 
(8)
a. Lalo!
Pergi! (go)
b* Oah (already)
Asp.sudah pergi
Sudah pergi (already went)

The command sentence is a sentence that expects someone to do something. The command in BS uses suprasegmental features of rising intonation. In this construction, the aspect is not justified to be presented at all, if it exists, the sentence becomes unacceptable as an example (8b). This is common in any language, it does not justify the presence of the subject NP or elements that have the same role as the subject. The following is the quantification construction.
dengan (people) gen (will) begawean (work)
Quant.banyak orang Asp.akan bekerja
Banyak orang akan bekerja (many people will work)
Lue? (many)
b. Sekeji? (few) dengan (people) gen (will) begawean (work)
Quant. orang Asp. bekerja
Sedikit orang akan bekerja (few people will work)
c.* Lue?(many?) gen (will) dengan (people) begawean (work)
Quan. Asp.akan orang bekerja
Banyak orang mau bekerja (many people will work)
d.* Sekeji? (few) dengan (people) gen (will) -ne (he or she or they)
Quant. orang Asp. pron begawean
Sedikit orang akan bekerja. (few people will work)

The quantification element of BS uses the word sekeji 'few', lue? 'Many' and others. In the quantification construction (9) it appears that the position of the element of aspect is after the subject NP and before the verb. If the position is changed to the position before the subject's NP, then the sentence becomes unacceptable such as in sentence (9c), and if pronominal exists, the sentence also becomes ungrammatical as in example (9d). Let us check relative construction below.

$$
\begin{aligned}
& \text { a. Ino (that) dengan (people) si (who is)gen (will) belanje (buy) no (that) } \\
& \text { Itu orang Rel.yang Asp belanja itu } \\
& \text { itu orang yang akan belanja itu (that is the people who want to buy ) } \\
& \text { b.* Ino (that) dengan (people) gen (Will) si (who is) belanje (buy) no (that) } \\
& \text { Itu orang Asp. Rel. belanja itu. } \\
& \text { Itu orang yang akan belanja itu (that is the people who want to buy ) } \\
& \text { c.* Ino (that) dengan (people) si (that is) gen (will)-ne (he or she) belenje (buy) } \\
& \text { no (that) } \\
& \text { Det. orang RelAsp. pron belanja itu } \\
& \text { Itu orangyang akan belanja itu. (that is the people who want to buy ) }
\end{aligned}
$$

The element of aspect in the BS's relative sentence seems to have to be after the relative si. If the position is moved to another position e.g. before the relative affix si, the sentence becomes ungrammatical. This can be seen in the sentence (10a) that is grammatical. The grammatical condition of the sentence is because the position of the element of aspect is after the relative element. Whereas, the sentence (10b) is not grammatical

Paridi, K., \& Sudika, I. N. (2018). Pronouns traces of grammar transformation version of government and binding. International Journal of Social Sciences and Humanities, 2(2), 175-186. https://doi.org/10.29332/ijssh.v2n2.162 
because the element of aspect has moved its position in which it precedes the relative element. Such relative construction will also not be grammatical if pronominal elements exist as shown in the example (10c). we can also see the control constructions below

$$
\begin{array}{llll}
\text { a. } & \text { Oah (alredy) -ku (I) nggite? (see) ie (him/her) } & \text { meroko? (smoke) } \\
\text { Asp pron melihat Pron.diamerokok } & \\
\text { Saya sudah melihat dia merokok (i saw him smoking) } & \text { meroko?(smoke) } \\
\mathrm{b}^{*} & \begin{array}{l}
\text { Ku (I) oah (ever) nggite? (see) ie (him/her) } \\
\text { pron Asp melihat Pron.diamerokok }
\end{array} & \\
& \text { Saya pernah melihat dia merokok. (i ever saw him smoking) }
\end{array}
$$

In the control construct, the element of aspect always fills the initial position of the sentence that is before the subject NP (11a). If the position is changed to another position, then the sentence becomes ungrammatical, for example (11b) which shows the position of the aspect that resides after the pronominal position. It is similar within the construction of raising.

In the rising construction (12) below there is an advanced element. We can identify the following example. It shows that at D-Structure, the position of aspect is before pronominal and before the verb, but when it is raised at the S-structure, pronominal does not appear as seen in example (12a) that is acceptable, so that the position of the aspect is immediately before the verb. If its position is changed to another position, the sentence becomes grammatically like the example (12d) which shows the position of the aspect before the word 'ruene' (seems). In addition, it can be seen that when it comes to raising, pronominal cannot exist. If the pronominal exists, the sentence becomes unacceptable (12c).

$$
\begin{aligned}
& \text { (12) a. Ruene (seem) Farid (Farid) gen (will) -ne (his or she) menang (win) } \\
& \text { rupanya Farid Asp.akan pron. menang } \\
& \text { Rupanya Farid akan menang (it seems like Farid will win) } \\
& \text { b. Farid (Farid) ruene (seems) gen (will) menang (win) } \\
& \text { Farid rupanyaAsp.akan menang } \\
& \text { Farid rupanya akan menang (it seems like Farid will win) } \\
& \begin{array}{l}
\text { c.* Farid (Farid) ruene (seem) gen (will) } \\
\text { Farid rupanya Asp.akan pron menang (he or she) menang (win) }
\end{array} \\
& \text { Rupanya Farid akan menang (it seems like Farid will win) } \\
& \text { d.* Farid (Farid) gen (will) ruene(seem) menang (win) } \\
& \text { Farid Asp rupanyamenang } \\
& \text { Rupanya Farid akan menang (it seems like Farid will win) }
\end{aligned}
$$

See the the construction of Focus Sentence below:

$$
\begin{aligned}
& \text { a. Bedul (Bedul) si (who is) gen (will) ule? (come home) ino (that) } \\
& \text { Bedul Fok.yang Asp.akan pulang itu } \\
& \text { Bedul yang akan pulang itu (Bedul who Will come home) }
\end{aligned}
$$

(that)

$$
\text { b.* Bedul(Bedul) gen (Will) si (who is) ule?(come home) no. }
$$

$$
\text { Bedul Asp.akan Fok.yang plang itu }
$$

Bedul yang akan pulang (Bedul who Will back home)

$$
\begin{array}{lllll}
\text { c.* Bedul (Bedul) } & \text { si (who is) } & \text { gen (Will) } & \text {-ne (he or seh) ule?(come home) no (that) } \\
\text { Bedul Fok. Asp. pron. pulang } & \text { itu. }
\end{array}
$$


Bedul yang akan pulang itu. (Bedul who Will back home)

In focus construction (13) it shows that the element of aspect is in the subject position of the subject NP and the element of focus si. This can be seen in example (13a) that is acceptable in BS. If the position is changed to another position e.g. to before the element of focus, the sentence becomes ungrammatical. When the pronominal element exists, the sentence also does not become grammatical as in example (13c) above.

Because the element of aspect is analyzed as Modal element, the existence of that element will be dominated by modal node which abbreviated M. Furthermore, that element will construct the projection of modal phrase which is abbreviated as MP. If it is represented in a tree diagram, the position of the element is before the element of Agr. As follows:

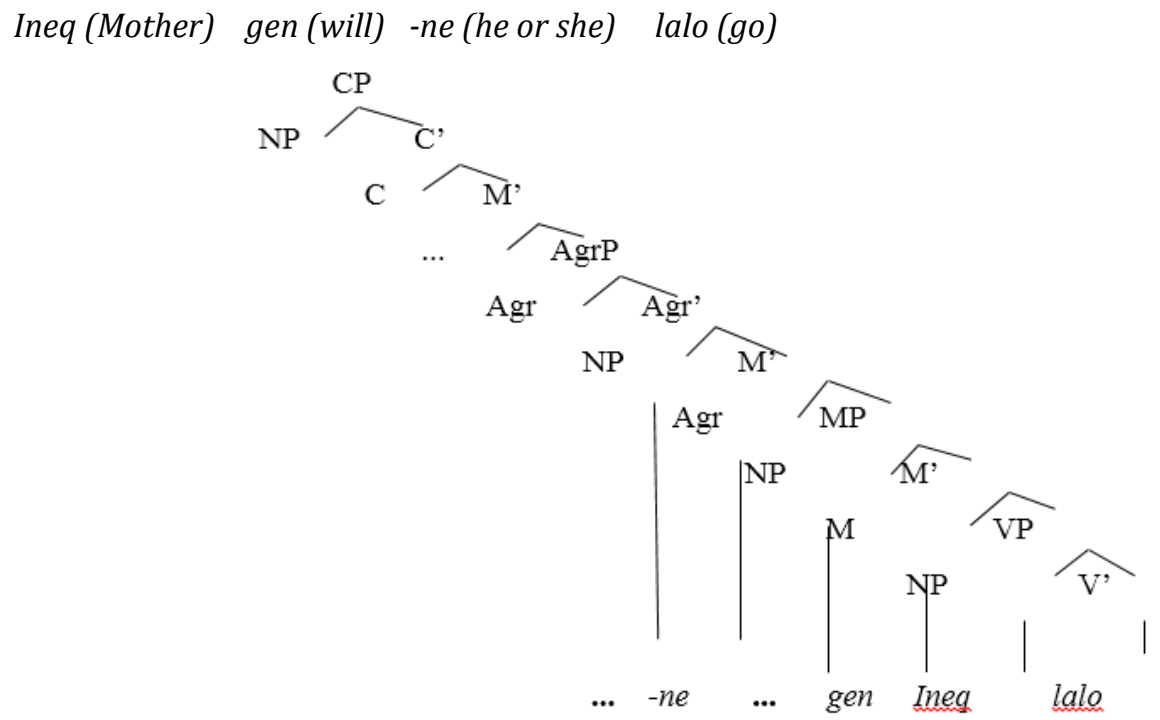

Referring to the above representation, it can be observed that the element of aspect 'gene' (will) lies below the vertex M and pron -ne is below the Agr node. From that representation NP Ineq (mother) is subject. Thus, the element occupies Spec. VP because it is an external argument V. To get the desired phonetic shape, the element of aspect 'gene' aspect element moves to the Spec position. Agr to get the case. Therefore, at the surface level, the representation of the elements will appear like this.

Paridi, K., \& Sudika, I. N. (2018). Pronouns traces of grammar transformation version of government and binding. International Journal of Social Sciences and Humanities, 2(2), 175-186. https://doi.org/10.29332/ijssh.v2n2.162 
14. Ineq gen -ne lalo

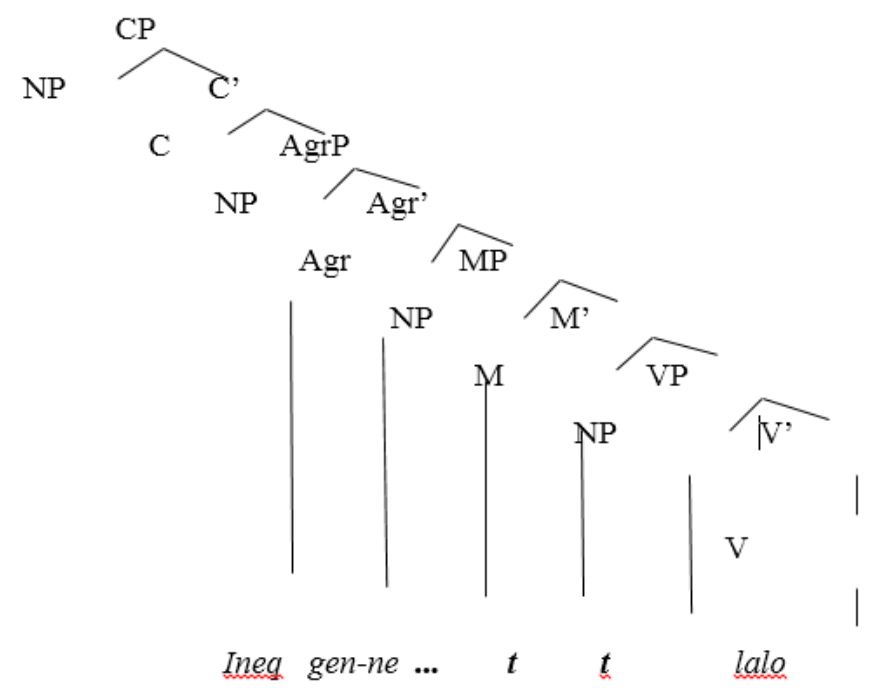

From the previous representation, it appears that the base position of the pronoun Ineq 'mother' is under the $N P, V P$ node, but with the transfer process, the personal pronoun Ineq moves to the position of $N P$, Agr. This is \# because every visible $N P$ should get a case from its verb. Besides, the trace marked by $t$ is the landing site or base position before the pronoun and other elements move.

\section{Conclusion}

From the aforementioned data analysis, it can be concluded that: 1) base position of the personal pronoun is under the node (Node) $N P, V P$, but with the transfer process, the personal pronoun is in the position of $N P$, $A g r$. This is because every visible NP should get a case from its verb; 2) the trace marked by $t$ is the landing site or base position before the pronoun and other elements move; 3 ) this theory is sufficient to give an idea of the position of the element of aspect and modal as the category of $M P$ in phrase structure. Considering the findings of this study, it is highly expected that further study focusing on language phenomena in Nusantara languages grounded in Government and Binding theory can be conducted to prove the claims of the theories in discovering the universality of the grammar of a language.

Conflict of interest statement and funding sources

The authors declared that they have no competing interest. This stud being reported in this publication was supported Udayana University and it has been reviewed and approved by IJSSH in accordance with its policy on objectivity in research.

\section{Statement of authorship}

The authors hereby declare that we are the original authors of this research. Besides, we have not used any sources other than those listed in the bibliography and identified as references. We further declare that we have not submitted this study at any other institution. In addition, the authors have approved the final article.

\section{Acknowledgments}

We would like to extend our gratitude to all those who have given assistance so that this article on the critical review of the literature can be delegated. We also express our gratitude to the input and assistance of the Faculty of Teacher Training and Education of Mataram University which has provided a forum for scientific advancement for the advancement of science, especially at the University of Mataram. 


\section{References}

1. Anita, D., Mbete, A. M., \& Mandala, H. (2018). Ecolexicon wealth of nautical expression in Kuta Lombok society. International Research Journal of Engineering, IT and Scientific Research (IRJEIS), 4(3), 17-22. View in (Google Scholar)

2. Baltin, M. R. (1982). A landing site theory of movement rules. Linguistic Inquiry, 13(1), 1-38. View in (Google Scholar)

3. Chomsky, N. (1981). Lectures on Government and Binding, Foris, Dordrecht.(1995) Minimalist Program. View in (Google Scholar)

4. Chomsky, N., \& Keyser, S. J. (1982). Some concepts and consequences of the theory of government and binding. MIT press.

View in (Google Scholar)

5. Haegeman, L. (1995). The syntax of negation (Vol. 75). Cambridge University Press. View in (Google Scholar)

6. Iriani, D. H. (2018). The Effect of Early English Learning on Psychology. International Journal of Social Sciences and Humanities (IJSSH), 2(1), 65-74.

View in (Google Scholar)

7. Mu'adz, H. M. (1996). Teori X-bar dan Beberapa Aspek Sintaksis Bahasa Indonesia. Dalam Soenjono Dardjowidjojo (ed.), 1928-1995.

View in (Google Scholar)

8. Paridi, K. (1997). “Government and Case dalam ”. (Laporan Penelitian) Universitas Mataram. View in (Google Scholar)

9. Paridi, K. (1997). “Struktur Frase Bahasa Indonesia: Kajian Berdasarkan Teori X-Bar”. (Laporan Penelitian) Universitas Mataram.

View in (Google Scholar)

10.Ruan, X. (2018). Engagement and negotiation: Exploring a tertiary female EFL teacher's professional agency in her career development in PR China. International Journal of Linguistics, Literature and Culture (IJLLC), 4(3), 46-63.

View in (Google Scholar)

11. Setiawan, I. (2016). Afiks me-/-kan dan me (n)-/-kan pada teks debat calon presiden republik indonesia periode tahun 2014-2019: tinjauan morfologi derivasi dan infleksi. Tutur: Cakrawala Kajian BahasaBahasa Nusantara, 2(2), 27-40.

View in (Google Scholar)

12. Stowell, T. A. (1981). Origins of phrase structure (Doctoral dissertation, Massachusetts Institute of Technology).

View in (Google Scholar)

Paridi, K., \& Sudika, I. N. (2018). Pronouns traces of grammar transformation version of government and binding. International Journal of Social Sciences and Humanities, 2(2), 175-186. https://doi.org/10.29332/ijssh.v2n2.162 


\section{Biography of Authors}

\begin{tabular}{|c|c|}
\hline & $\begin{array}{l}\text { Drs. Khairul Paridi, M.Hum., was born in East Lombok on December 31,1960. He } \\
\text { completed the study of elementary education up to high school in his hometown. } \\
\text { Furthermore, he continued his bachelor and master degree education majoring in } \\
\text { Indonesian Language and Literature Education at Mataram University. He } \\
\text { completed his postgraduate at Department of Linguistics, Udayana University. } \\
\text { Now, he is a lecturer at the undergraduate program of Language Education, } \\
\text { Indonesian and Regional Literature at Mataram University. }\end{array}$ \\
\hline & $\begin{array}{l}\text { Drs. I Nyoman Sudika, M.Hum., was born in Bali on December 31, 1962. He } \\
\text { completed the study of elementary education up to high school in his hometown. } \\
\text { Furthermore, he continued his bachelor and master degree education majoring } \\
\text { Indonesian Language and Literature Education and He completed his } \\
\text { postgraduate at Department of Linguistics, Udayana University. Now, he is a } \\
\text { lecturer at the undergraduate program of Language Education, Indonesian and } \\
\text { Regional Literature at Mataram University. } \\
\text { Email: dika_n62@yahoo.com }\end{array}$ \\
\hline
\end{tabular}

